\title{
PENGISIAN JABATAN PRESIDEN DAN PRESIDENTIAL THRESHOLD DALAM DEMOKRASI KONSTITUSIONAL DI INDONESIA
}

\author{
Fuqoha \\ Program Studi Ilmu Hukum Universitas Serang Raya \\ Email : fuqoha23@gmail.com
}

\begin{abstract}
Abstrak
Pengisian jabatan Presiden dan wakil Presiden merupakan salah satu unsur penting penyelenggaraan negara. Dalam konstitusi dijelaskan bahwa pemegang kekuasaan pemerintahan adalah Presiden dan dibantu oleh seorang wakil Presiden. Berdasarkan konstitusi negara Indonesia telah diatur mengenai mekanisme pengisian jabatan Presiden dan wakil Presiden. Prinsip konstitusi negara Indonesia atau undang-undang dasar negara Republik Indonesia mengandung prinsip demokrasi. Prinsip demokrasi memungkinkan setiap orang memiliki hak dan kesempatan yang sama dalam membangun masyarakat, bangsa dan negara yang menjadi hak konstitusional. Pasca amandemen UUD, mekanisme pengisian jabatan Presiden dan wakil Presiden diatur dalam Pasal 6A UUD 1945 yang mengharuskan calon Presiden dan wakil Presiden diusulkan oleh partai politik. Pengaturan lebih lanjut mengenai pengisian jabatan Presiden diatur melalui Undang-Undang No. 7 Tahun 2017 dimana ketentuan pencalonan Presiden dan wakil Presiden oleh partai politik diharuskan memenuhi presidential threshold. Adanya ketentuan tersebut bertentangan dengan prinsip demokrasi konstitusional. Dalam Pasal 6A UUD 1945 bertentangan dengan hak konstitusional setiap orang untuk menggunakan hak mencalonkan diri (the right to be candidate) sebagai Presiden dan/atau wakil Presiden. Melalui Pasal 222 UU. No.7 Tahun 2017 mengkebiri hak konstitusional partai politik dalam hak mengajukan calon (the right to propose candidate).
\end{abstract}

Kata kunci : Pengisian Jabatan Presiden, Presidential threshold, Demokrasi Konstitusional.

\section{PENDAHULUAN}

Istilah Presiden sering diartikan sebagai pemimpin dalam suatu negara yang berbentuk Republik. Berdasarkan pada ketentuan Undang-Undang Dasar (UUD) 1945, Indonesia merupakan Negara kesatuan yang berbentuk Republik. Georg Jellineck ${ }^{1}$ mengklasifikasi suatu pemerintahan, bahwa apabila kehendak negara terjelma dari kehendak rakyat, maka dapat dikategorikan sebagai pemerintahan Republik. Sebagai negara Republik maka kekuasaan pemerintahan di Indonesia dipimpin oleh seorang Presiden, yang diatur dalam UUD 1945 Pasal 4 Ayat (1) Presiden Republik

${ }^{1}$ I Gede Pantja Astawa dan Suprin Na'a. 2009. Memahami Ilmu Negara Dan Teori Negara. Cet. 1. Bandung : Refika Aditama, hlm. 104.
Indonesia memegang kekuasaan pemerintahan menurut Undang-Undang Dasar.

Pada prinsipnya dalam hukum tata negara, Presiden merupakan suatu jabatan yang menunjukan tugas dan fungsi serta kewenangannya. Logeman ${ }^{2}$ menganggap pengertian inti dari hukum tata Negara adalah Jabatan. Pengisian jabatan negara merupakan salah satu unsur penting dalam hukum tata negara, sebab tanpa diisi oleh pejabat maka fungsi-fungsi jabatan negara tidak dapat dilaksanakan sebagaimana mestinya. ${ }^{3}$

2 Harun Alrasid. 1999. Pengisian Jabatan Presiden. Jakarta : Pustaka Utama Grafiti, hlm. 5 .

Bagir Manan.2003. Lembaga Kepresidenan. Yogyakarta. FH UII Press. Cet. Ke. 2. hlm. 75 . 
Sebagai negara hukum, segala tindakan penyelenggaraan negara termasuk pengisian suatu jabatan negara harus sesuai dengan ketentuan-ketentuan hukum. Dalam UUD 1945 telah ditegaskan dalam Pasal 1 Ayat (3) negara Indonesia adalah negara hukum. Mekanisme pengisian jabatan Presiden dapat dilakukan dengan banyak cara, antara lain pengangkatan, pemilihan, pewarisan yang sifatnya turun temurun, penggiliran atau rotasi pemangkuan karena jabatan (ex officio), dan lain sebagainya. ${ }^{4}$

Dalam sistem ketatanegaraan Indonesia pengisian jabatan Presiden telah diatur dalam Konstitusi atau UUD 1945. Sejak negara Indonesia merdeka, jabatan Presiden Indonesia telah diisi oleh beberapa Presiden, yaitu Soekarno, Soeharto, B.J. Habibie, Abdurahman Wahid, Megawati Soekarno Putri, Susilo Bambang Yudhoyono dan Joko Widodo. Mekanisme pengisian jabatan Presiden sejak awal kemerdekaan melalui cara yang berbeda-beda, Soekarno dipilih oleh Panitia Persiapan Kemerdekaan Indonesia (PPKI) yang didasarkan pada Aturan Peralihan Pasal III UUD 1945 yang berbunyi untuk pertama kalinya Presiden dan wakil Presiden dipilih oleh PPKI. Soeharto menjadi Presiden kedua Indonesia melalui mekanisme pengangkatan dengan calon tunggal yang didasarkan pada Ketetapan MPR No.2 Tahun 1973 tentang tata cara pemilihan Presiden dan wakil Presiden. Presiden Ketiga B.J Habibie dengan jabatan sebelumnya adalah wakil Presiden sesuai ketentuan UUD 1945 dalam Pasal 8 Ayat (1) Jika Presiden mangkat, berhenti, diberhentikan, atau tidak dapat melakukan kewajibannya dalam masa jabatannya, ia digantikan oleh wakil Presiden sampai habis masa jabatannya. Presiden Abdurahman Wahid dipilih oleh Majelis Permusyawaratan Rakyat (MPR) sesuai ketentuan UUD 1945 sebelum amandemen Pasal 6 Ayat (2) Presiden dan wakil Presiden dipilih oleh majelis permusyawaratan rakyat dengan suara yang terbanyak. Presiden

\footnotetext{
${ }^{4}$ Harun Alrasid. Op.cit. hal. 23.
}

selanjutnya Megawati, menjadi Presiden sesuai ketentuan Pasal 8 Ayat (1) sepertinya halnya B.J habibie yang menggantikan Presiden sebelumnya. ${ }^{5}$

Dalam prinsipnya demokrasi dapat diklasiifikasi menjadi demokrasi secara langsung (direct democracy) dan demokrasi melalui perwakilan (representative democracy). ${ }^{6}$ Pemilihan Presiden sebelum amandemen UUD 1945, menunjukan bahwa pengisian jabatan Presiden dilakukan melalui demokrasi berdasarkan perwakilan (representative democracy). Sedangkan demokrasi secara langsung (direct democracy) dalam sistem pengisian jabatan Presiden di Indonesia dimulai setelah adanya amandemen UUD 1945 dimana berdasarkan ketentuan hasil amandemen dalam Pasal 6A Ayat (1) Presiden dan wakil Presiden dipilih dalam satu pasangan secara langsung oleh rakyat.

Prinsip demokrasi memberikan kebebasan dan ruang bagi seluruh rakyat untuk dapat membangun negara dan/atau pemerintahan. Demokrasi di Indonesia dijamin melalui konstitusi negara dalam bentuk UUD 1945 sebagai hukum dasar dalam menjalankan negara. Demokrasi yang didasarkan pada konstitusi menunjukan demokrasi konstitusional. Dengan demikian setiap hak rakyat dijamin oleh konstitusi dan tidak dibenarkan adanya tindakan sewenangwenang pemerintah terhadap hak-hak rakyat.

Salah satu hak warga negara yang dijamin oleh konstitusi negara yaitu berkenaan dengan pemilihan umum, yang diatur dalam UUD 1945 Pasal 22E tentang pemilihan umum untuk memilih anggota dewan perwakilan rakyat, dewan perwakilan daerah, Presiden dan wakil Presiden dan dewan perwakilan rakyat daerah. Dalam

5 Sulardi. 2011. Dinamika Pengisian Jabatan Presiden dan Pemberhentian Presiden dan Wakil Presiden di Indonesia. Jurnal UNISIA Vol.33 No.74, hlm. 124. (diunduh dari journal.uii.ac.id).

${ }^{6}$ Miriam Budiardjo. 2008. Dasar-Dasar Ilmu Politik. Edisi Revisi. Cetakan Kedua. Jakarta : Gramedia Pustaka Utama, hlm. 109. 
pemenuhan hak-hak warga negara tersebut, secara langsung dijamin oleh konstitusi dalam Pasal 28 UUD 1945 tentang hak asasi manusia bahwa setiap warga negara berhak memperoleh kesempatan yang sama serta berhak memajukan dirinya untuk membangun masyarakat, bangsa dan negara.

Oleh karena itu, setiap warga negara Indonesia memiliki kesempatan dan hak yang sama untuk maju dalam suatu pemilihan umum yang salah satunya adalah pemilihan Presiden dan wakil Presiden Republik Indonesia. Dalam sistem ketatanegaraan Indonesia, Sistem pemilihan Presiden dan wakil Presiden diatur dalam UUD 1945 Pasal 6 Ayat (1) calon Presiden dan calon wakil Presiden harus warga negara Indonesia sejak kelahirannya dan tidak pernah menerima kewarganegaraan lain karena kehendaknya sendiri, tidak pernah menghianati negara, serta mampu secara rohani dan jasmanai untuk melaksanakan tugas dan kewajiban sebagai Presiden dan wakil Presiden. Dengan demikian setiap warga negara Indonesia memiliki kesempatan untuk menjadi Presiden dan wakil Presiden karena telah dijamin oleh konstitusi negara.

Mekanisme pengisian jabatan Presiden dan wakil Presiden lebih lanjut diatur dalam konstitusi dalam Pasal 6A Ayat (2) pasangan calon Presiden dan wakil Presiden diusulkan oleh partai politik atau gabungan partai politik peserta pemilihan umum sebelum pelaksanaan pemilihan umum. Dengan ketentuan tersebut, maka setiap warga negara Indonesia yang ingin menjadi Presiden dan/atau wakil Presiden harus mendapat dukungan dan diusung oleh partai politik. Mekanisme pengisian jabatan Presiden ini secara tersirat bertujuan untuk menciptakan keseimbangan antara legislatif dan eksekutif. Adanya ketentuan tersebut, menciptakan semakin rendahnya peluang bagi setiap warga negara yang ingin menjadi Presiden dan/atau wakil Presiden, karena untuk menjadi Presiden harus mempunyai dukungan dan diusung partai politik.
Mekanisme pengusulan calon Presiden berdasarkan ketentuan dalam konstitusi cenderung pada representative democracy yang diwakilkan melalui partai politik pemenang pemilu. Bakal calon Presiden secara konstitusional harus diusulkan oleh partai politik yang ada diparlemen untuk kemudian calon Presiden dipilih langsung oleh rakyat (direct democracy). Konsepsi tersebut menunjukan bahwa negara Indonesia dalam sistem pengisian jabatan Presiden menganut prinsip demokrasi konstitusional, kebebasan setiap warga negara, setiap hak warga negara diatur oleh konstitusi negara.

Dengan demikian, hak setiap warga negara dalam sistem pengisian jabatan Presiden di Indonesia tetap terjamin dalam konstitusi dan hanya dibatasi oleh ketentuan yang mengharuskan calon Presiden harus diusulkan oleh partai politik pemenang pemilu yang lebih lanjut diatur melalui undang-undang. Selain pembatasan dalam pengsisian jabatan Presiden melalui usulan partai politik, terdapat presidential threshold atau ambang batas calon Presiden yang ditentukan dalam undang-undang pemilihan umum Presiden.

Dalam ketentuan konstitusi tidak disyaratkan mengenai presidential threshold, berarti adanya ambang batas calon Presiden inskontitusional yang mencederai prinsip demokrasi konstitusional itu sendiri. Munculnya ketentuan ambang batas merujuk pada kesimbangan parlemen dan Presiden dalam prinsip check and balance, bahwa dalam penyelenggaraan pemerintahan harus ada keseimbangan antara legislatif dan eksekutif. Check and balance merupakan elemen esensial yang diatur dalam konstitusi atas prinsip pemisahan kekuasaan agar kekuasaan tertentu tidak berkuasa penuh. ${ }^{7}$ Keseimbangan dalam pemerintahan sangat diperlukan agar dapat mencapai tujuan-tujuan pemerintah yang telah ditetapkan.

\footnotetext{
${ }^{7}$ Janedjri M. Gaffar. Hukum Pemilu
}

Dalam Yurisprudensi Mahkamah Konstitusi. Jakarta : Konstitusi Pres. 2013, hlm. 4. 
Pengaturan mengenai Presidential threshold dituangkan dalam undang-undang No. 23 Tahun 2003 yang dirubah dengan undang-undang No.42 Tahun 2008 tentang pemilihan umum Presiden dan wakil Presiden Pasal 9 bahwa pasangan calon Presiden diusulkan oleh partai politik atau gabungan partai politik peserta pemilu yang memenuhi perolehan suara $20 \%$ dari jumlah kursi DPR atau memperoleh $25 \%$ dari suara sah nasional. Adanya ketentuan tersebut menghilangkan hak konstitusional partai politik dalam mencalonkan Presiden serta hak masyarakat secara luas untuk menentukan pilihan pada calon Presiden yang berkualitas tidak hanya calon Presiden yang disenangi oleh partai politik sebagai penguasa diparlemen.

Dalam ketentuan terbaru mengenai sistem pemilihan umum, yang didasarkan pada Putusan Mahkamah Konstitusi (MK) No. 14/PUU-XI/2013 yang memutuskan pemilihan umum secara serentak. Ketentuan terkait presidential threshold tidak dimungkinkan dapat terwujud, dikarenakan pemilihan Presiden dan pemilihan Dewan Perwakilan Rakyat (DPR) dilaksanakan pada saat yang bersamaan. Adanya perubahan undang-undang terkait ketentuan presidential threshold terkesan memaksakan bahwa calon Presiden dan wakil Presiden harus memenuhi ambang batas dukungan legislatif atau Dewan Perwakilan Rakyat. ketentuan tersebut diatur dalam undang-undang No.7 Tahun 2017 Pasal 222 "pasangan calon (Presiden) diusulkan oleh partai politik atau gabungan partai politik peserta pemilu yang memenuhi persyaratan perolehan kursi paling sedikit 20\% dari jumlah kursi DPR atau memperoleh 25\% dari suara sah secara nasional pada pemilu anggota DPR sebelumnya".

Pengisian jabatan Presiden sebagai lembaga eksekutif, yang harus ditentukan oleh kekuasaan parlemen atau legislatif sangat bertentangan dengan semangat dan cita demokrasi. Lembaga eksekutif dan legislatif merupakan dua institusi yang berbeda dan memiliki legitimasi yang tidak sama. Secara konstitusional pengisisan jabatan Presiden dalam Pasal 6A Ayat (1) bahwa Presiden dan wakil Presiden dipilih dalam satu pasangan secara langsung oleh rakyat. dengan demikian penetapan presidential threshold tidak sesuai dengan prinsip demokrasi konstitusional. Adanya presidential threshold menggambarkan adanya pengelompokan penguasa parlemen untuk mempersempit ruang bagi calon-calon Presiden yang diharapkan oleh masyarakat secara umum.

\section{PERUMUSAN MASALAH DAN METODE PENELITIAN}

Didasarkan pada latar belakang masalah yang diuraikan, maka dirumuskan permasalahan yang perlu dikaji yakni bagaimana pengisian jabatan Presiden Republik Indonesia dalam menjaga stabilitas politik melalui presidential threshold ditinjau dari prinsip demokrasi konstitusional?

Dalam penelitian ini digunakan model penelitian kualitatif yang bersifat deskriptif analitis, dengan maksud mengumpulkan data selengkap mungkin untuk menggambarkan fakta-fakta secara sistematis dan terintegrasi. Penelitian ini menggunakan pendekatan yuridis normatif, suatu pendekatan yang mengkonsepsikan hukum sebagai norma, kaidah atau asas untuk menganalisis data secara sistematis dengan peraturan-peraturan yang ada. ${ }^{8}$

\section{KERANGKA KONSEPTUAL}

Jabatan Presiden dikenal sebagai kepala Negara atau pemimpin suatu Negara. Jabatan menunjukan tugas dan fungsi dalam organisasi atau institusi seperti halnya Negara yang terdiri dari jabatan-jabatan. Harusn Alrasid $^{9}$ mengemukakan bahwa Negara merupakan organisasi yang terdiri atas jabatan-jabatan. Dalam hal jabatan Presiden maka jabatan menunjukan tugas dan fungsi dalam organisasi yang disebut Negara. Dalam

8 Soerjono Soekanto dan Sri Mamuji. 2006. Penelitian Hukum Normatif. Jakarta : Rajawali Press, hlm. 14-15.

${ }^{9}$ Harun Alrasid. Op.cit. hlm. 6. 
sistem pengisian Jabatan Presiden di Indonesia dituangkan dalam ketentuan Konstitusi sebagai bagian dari ciri Negara demokrasi. Harusn Alrasid ${ }^{10}$ menyatakan jabatan Presiden ialah sebagai kepala Negara (head of state) setara kedudukan raja atau ratu, oleh karena itu mengenai pengisian jabatan Presiden dicantumkan dalam peraturan Negara tertinggi yaitu UndangUndang Dasar atau konstitusi.

Pengisian jabatan Presiden yang merupakan kepala negara di Indonesia telah diatur dalam Undang-Undang Dasar Pasal 6 dan Pasal 6A. Berdasarkan prinsip konstitusional, negara Indonesia memiliki karakteristik sebagai negara dengan prinsip demokrasi yang dituangkan dalam Pasal 28 Undang-Undang Dasar Negara Republik Indonesia 1945. Ditinjau dari sejarahnya lahirnya demokrasi didasari suatu teori rasionalitas atau sering disebut social control (kontrak sosial). ${ }^{11}$ Pada prinsipnya kontrak sosial menunjukan adanya kesepakatan mengikat antara penguasa dengan rakyat yang terbentuk dalam ketentuan-ketentuan yang memberikan jaminan kekuasaan bagi penguasa serta menjamin terpenuhinya hakhak bagi rakyat. Diantara hak-hak yang dijamin pada teori kontrak sosial, muncul gagasan tentang hak-hak politik bagi rakyat yang dicetuskan oleh John Locke dan Montesquieu. ${ }^{12}$

Richard A. Posner ${ }^{13}$ mengkonsepsi teori demokrasi menjadi demokrasi deliberatif (deliberative democracy) dan demokrasi elit (elite democracy). Dalam demokrasi deliberatif dikonsepsikan secara idealis, teoretis dan top down yang berarti terdapat gagasan bahwa setiap orang memiliki hak yang sama untuk berpartisipasi dalam pemerintahan. Sedangkan demokrasi elit dikonsepsikan sebagai demokrasi secara

\footnotetext{
${ }^{10} \mathrm{Ibid}, \mathrm{hlm} .2$.

${ }^{11}$ Miriam Budiardjo. Op.cit. hlm. 111.

${ }^{12}$ Ibid.

13 Janedjri M. Gaffar. 2013.Demokrasi
} Dan Pemilu Di Indonesia. Jakarta : Konstitusi Press, hlm.20-21. pragmatis bahwa demokrasi didasarkan pada praktik aktual demokrasi dalam berbagai bentuk institusionalisasi serta menilai bahwa demokrasi merupakan kompetisi antara kepentingan politisi untuk mendapatkan dukungan rakyat.

Munir Fuady ${ }^{14}$ mengkonsepsikan pelaksanaan prinsip demokrasi, terdapat batasan-batasannya. Akan tetapi batasan tersebut tidak dibenarkan menghilangkan atau mengebiri makna demokrasi itu sendiri. Dalam perkembangannya, fenomena dalam demokrasi terus berubah, oleh Munir Fuady digambarkan dengan demokrasi riil (rasional) menjadi demokrasi selebritis (irrasional). Demokrasi selebritis (irrasional) sering berujud dalam bentuk pencitraan diri dengan mengandalkan media massa. Dalam demokrasi yang mengandalkan pencitraan, kandidat tidak berbasis pada kompetensi dan kualitas tetapi didasarkan pada popularitas dan konektivitas. Demokrasi rasional terwujud apabila terpenuhi unsur-unsur dalam pemilihan umum sebagai berikut ${ }^{15}$ :

1. Sistem demokrasi yang rasional. Dalam pemilihan umum perlu suatu sistem pencalonan dan pemilihan yang tepat, sistem pemilihan yang efektif dan efisien dan sebagainya.

2. Partai politik yang rasional. Partai politik harus memiliki komitmen dan prosedur kompetisi internal yang baik yang disodorkan pada rakyat untuk dipilih, bukan atas dasar keluarga, pemilik uang, atau pencitraan.

3. Kandidat yang akan dipilih yang rasional. Kandidat yang dipilih dalam pemilihan umum memiliki kualitas tinggi dan berakhlak mulia, bukan yang banyak pencitraan dengan menjual tampang di media atau sekedar memiliki elektabilitas tinggi berdasarkan hasil survey.

4. Voter yang cerdas. Para pemilih harus diberikan pendidikan dan pencerahan sehingga menjadi pemilih yang

14 Munir Fuady. 2010. Konsep Negara Demokrasi. Jakarta : Refika Aditama, hlm. 24.

${ }^{15}$ Ibid, hlm. 25-27. 
cerdas yang mampu membedakan mana kandidat yang baik dan mana kandidat yang hanya petualangan politik.

5. Budaya demokrasi yang rasional. Untuk mendapatkan budaya demokrasi yang rasional memang memerlukan waktu, tetapi perlu secara sadar dibina terus menerus.

Konsep demokrasi memberikan gambaran bahwa dalam prinsip demokrasi rakyat memiliki kekuasaan dalam negara yang dituangkan dalam suatu konstitusi negara. Firdaus ${ }^{16}$ mengkonsepsikan bahwa konstitusi berfungsi sebagai landasan demokrasi yang berarti eksistensi demokrasi ditentukan sebuah landasan dalam bentuk konstitusi. Secara substansial, konstitusi merupakan sumber dan landasan yang menentukan batasbatas legitimasi dan validitas kekuasaan yang sering disebut konstitusionalisme. ${ }^{17}$ Konsep konstitusionalisme menunjukan bahwa demokrasi harus berdasar atas hukum, dimana demokrasi memberikan kebebasan namun disisi lain demokrasi juga memerlukan kerangka aturan agar dapat tertib dan teratur serta bertentangan dengan kebebasan orang yang lain.

Merujuk pada prinsip demokrasi dan konstitusional, pengisian jabatan Presiden di Indonesia sesuai ketentuan konstitusi merupakan upaya untuk menciptakan keteraturan dalam mekanisme pengisian jabatan Presiden yang demokratis. Ketentuan salah satu syarat calon Presiden dan wakil Presiden mengenai calon diusulkan oleh partai politik atau gabungan partai politik,menunjukan adanya batasan dalam pengisian jabatan Presiden. Mekanisme tersebut menunjukan eksistensi dari partai politik dalam membentuk pemerintahan. Firdaus $^{18}$ mengemukakan bahwa partai politik bagian dari kebebasan dan kesetaraan

16 Firdaus. 2015. Constitutional Engineering. Desain Stabilitas Pemerintahan Demokrasi \& Sistem Kepartaian. Bandung : Yrama Widya. hlm. 80.

\footnotetext{
${ }^{17}$ Ibid. hlm. 81

${ }^{18}$ Ibid. hlm. 15.
}

politik untuk berpartisipasi dalam pemerintahan.

Partai politik merupakan wadah bagi masyarakat untuk berpartisipasi dalam pemerintahan yang dijamin dalam Konstitusi untuk menduduki jabatan di parlemen. Oleh karena itu, untuk menciptakan kesimbangan antara parlemen dan Presiden dalam prinsip check and balance, bahwa dalam penyelenggaraan pemerintahan harus ada keseimbangan antara legislatif dan eksekutif. Namun demikian, hal tersebut tidak diperkenankan bertentangan dengan hak konstitusional yang meliputi hak memilih (the right to vote), hak untuk mencalonkan diri (the right to be candidate), dan hak mengajukan calon (the right to propose candidate). ${ }^{19}$

\section{PEMBAHASAN}

1. Sistem Pengisian Jabatan Presiden dan Presidential threshold Dalam Prinsip Demokrasi Konstitusional.

Pemilihan umum merupakan salah satu unsur negara demokratis yang memberikan jalan bagi warga negara untuk terlibat dalam pemerintahan. Sebagai negara yang demokratis, pemilihan umum diselenggarakan sebagai pengakuan atas hak setiap warga negara yang dijamin dalam konstitusi. Diantara pemilihan umum di Indonesia yaitu pemilihan umum Presiden dan wakil Presiden Republik Indonesia yang diatur dalam konstitusi atau undang-undang dasar 1945.

Ketentuan dalam undang-undang dasar mengenai pengisian jabatan Presiden pasca amandemen yang diatur melalui Pasal 6A tidak sesuai dengan prinsip-prinsip demokrasi (kedaulatan rakyat). Setiap warga negara secara konstitusional memiliki hak yang dijamin dalam Pasal 28 undang-undang dasar 1945. Ketentuan pengisian jabatan Presiden berpotensi melanggar hak konstitusional setiap warga negara yang hendak

19 Janedjri M. Gaffar. Hukum Pemilu Dan... Op.cit. hlm. 206. 
mencalonkan diri menjadi Presiden dan/atau wakil Presiden.

Pengisian jabatan Presiden dan wakil Presiden dituangkan dalam Undang-Undang Dasar pasca amandemen Pasal 6A Ayat (2) pasangan calon Presiden dan wakil Presiden diusulkan oleh partai politik atau gabungan partai politik peserta pemilihan umum sebelum pelaksanaan pemilihan umum. Berdasarkan prinsip-prinsip demokrasi, pengisian jabatan Presiden dan wakil Presiden di Indonesia melanggar hak konstitusional yang dijamin secara tegas oleh konstitusi. Dalam Pasal 28C Ayat (2) setiap orang berhak untuk memajukan dirinya dalam memperjuangkan haknya secara kolektif untuk membangun masyarakat, bangsa dan negaranya. Selanjutnya Pasal 28D Ayat (3) setiap warga negara berhak memeperoleh kesempatan yang sama dalam pemerintahan.

Potensi pelanggaran hak konstitusional warga negara yang dijamin konstitusi berkenaan dengan calon Presiden dan/atau wakil Presiden diusulkan oleh partai politik atau gabungan partai politik. Dengan ketentuan tersebut mempersempit peluang warga negara yang ingin mencalonkan diri sebagai Presiden dan/atau wakil Presiden. Peluang untuk menjadi Presiden dan/atau wakil Presiden hanya dimiliki oleh orangorang partai politik atau orang-orang yang disenangi oleh partai politik.

Persoalan ini, sangat bertentangan dengan hak konstitusional dalam berdemokrasi seperti diungkapkan Janedjri M. Gaffar bahwa setiap orang memiliki hak untuk mencalonkan diri (the right to be candidate). Dengan demikian, jika didasarkan pada Pasal 6A UUD 1945 maka setiap orang tidak memiliki hak untuk mencalonkan diri sehingga berpotensi melanggar hak konstitusional. Dikatakan berpotensi karena, hak konstitusional itu masih dapat diperoleh apabila warga negara diusulkan oleh partai politik atau gabungan partai politik.

Partai politik seperti dikatakan Firdaus merupakan bagian dari kebebasan dan kesetaraan politik untuk berpartisipasi dalam pemerintahan yang demokratis. Giovani Sartori dalam Firdaus menggambarkan partai politik sebagai suatu perbendaharaan dalam peradaban politik demokrasi yang menjadi sarana mobilisasi kekuatan kelompok politik. ${ }^{20}$ Dalam pandangan hak konstitusional yang dikatakan oleh Janedri M. Gaffar, melalui partai politik masih memungkinkan warga negara untuk mempertahankan hak untuk mencalonkan diri (the right to be candidate) dan/atau memalui partai politik dapat mengajukan calon (the right to propose candidate).

Hak konstitusional dalam pengisian jabatan Presiden dan/atau wakil Presiden yang hanya melalui partai politik, harus sesuai dengan prinsip demokrasi rasional. Munir Fuady menjabarkan demokrasi rasional diantaranya adalah partai politik yang rasional dan kandidat yang akan dipilih yang rasional. Partai politik harus memiliki komitmen dan prosedur kompetisi internal yang baik untuk dicalonkan sebagai Presiden dan/atau wakil Presiden. Selain kompetisi internal partai politik-pun seharusnya melakukan penjaringan calon atau kandidat Presiden dan/atau wakil Presiden diluar kader internal untuk memberikan peluang bagi warga negara yang lain, sehingga calon Presiden yang disodorkan pada rakyat untuk dipilih merupakan calon yang berkualitas dan memiliki kapasitas bukan atas dasar kekeluargaan, pemilik uang, atau pencitraan.

Selain itu, kandidat calon Presiden dan/atau wakil Presiden yang dipilih dalam pemilihan umum harus memiliki kualitas tinggi dan berakhlak mulia, bukan yang banyak pencitraan dengan menjual tampang di media atau sekedar memiliki elektabilitas tinggi berdasarkan hasil survey. Munir Fuady membagi kedalam dua model demokrasi yaitu demokrasi rasional dan irrasional. Demokrasi irrasional terjadi manakala calon yang diusulkan partai politik berdasarkan pada pencitraan diri dengan mengandalkan media massa dimana kandidat tidak berbasis pada

\footnotetext{
${ }^{20}$ Firdaus. Op. cit. hlm. 134.
} 
kompetensi dan kualitas tetapi didasarkan pada popularitas dan konektivitas.

Didasarkan pada prinsip demokrasi konstitusional, maka pengisian jabatan Presiden dan/atau wakil Presiden sesuai dengan kehendak rakyat. dimana warga negara memiliki jaminan terhadap hak konstitusionalnya dalam membangun masyarakat, bangsa dan negaranya. Hal tersebut sesuai dengan demokrasi rasional bahwa dalam pemilihan umum perlu suatu sistem pencalonan dan pemilihan yang tepat, sistem pemilihan yang efektif dan efisien dan sebagainya yang didasarkan pada konstitusi.

Selain ketentuan konstitusi dalam pengisian jabatan Presiden dan wakil Presiden yang diatur melalui Pasal 6A undang-undang dasar. Mekanisme pemilihan umum Presiden dan wakil Presiden pasca amandemen diatur melalui undang-undang. undang-undang tentang pemilihan umum Presiden dan wakil Presiden diatur dalam undang-undang No. 23 Tahun 2003 yang dirubah dengan undangundang No.42 Tahun 2008 dan terakhir dirubah dengan undang-undang No.7 Tahun 2017.

Dalam ketentuan yang dituangkan dalam undang-undang tersebut mengatur mengenai persyaratan bagi bakal calon Presiden dan wakil Presiden. setiap ketentuan dalam undang-undang pemilihan umum Presiden dan wakil Presiden menjunjung semangat demokrasi yang berlandaskan konstitusi. Namun demikian, salah satu ketentuan dalam Pasal 222 Undang-Undang No.7 Tahun 2017 menyatakan bahwa pasangan calon diusulkan oleh partai politik atau gabungan partai politik peserta pemilu yang memenuhi persyaratan perolehan kursi paling sedikit $20 \%$ dari jumlah kursi DPR atau memperoleh $25 \%$ dari suara sah secara nasional pada pemilu anggota DPR sebelumnya.

Ketentuan tersebut menunjukan adanya presidential threshold atau ambang batas bagi pencalonan Presiden dan/atau wakil Presiden. Ketentuan tersebut bertentangan dengan prinsip demokrasi konstitusional, dimana dalam konstitusi telah dijamin hak-hak konstitusional warga negara. Diantara hak konstitusional seperti dijelaskan Janedjri M. Gaffar yaitu meliputi hak memilih (the right to vote), hak untuk mencalonkan diri (the right to be candidate), dan hak mengajukan calon (the right to propose candidate).

Hak untuk mencalonkan diri (the right to be candidate) telah dibatasi oleh konstitusi yang mencederai makna kebebasan warga negara untuk membangun masyarakat dan negara yang dijamin konstitusi. Dengan adanya ketentuan presidential threshold jelas bahwa pemerintahan semakin membatasi hak mengajukan calon (the right to propose candidate) dalam pengisian jabatan Presiden dan/atau wakil Presiden oleh partai politik. Hal ini bertentangan dengan prinsip demokrasi konstitusional, dimana secara konstitusional tidak diatur adanya ambang batas bagi pencalonan Presiden dan wakil Presiden.

Pengisian jabatan Presiden yang ditentukan oleh kekuasaan parlemen atau legislatif sangat bertentangan dengan semangat dan cita demokrasi. Secara konstitusional pengisisan jabatan Presiden dalam Pasal 6A Ayat (1) bahwa Presiden dan wakil Presiden dipilih dalam satu pasangan secara langsung oleh rakyat dan Pasal 6A Ayat (2) pasangan calon Presiden dan wakil Presiden diusulkan oleh partai politik atau gabungan partai politik peserta pemilihan umum sebelum pelaksanaan pemilihan umum. Dengan demikian penetapan presidential threshold tidak sesuai dengan prinsip demokrasi konstitusional, karena tidak ditentukan didalam konstitusi. Adanya presidential threshold menggambarkan adanya pengelompokan penguasa parlemen untuk mempersempit ruang bagi calon-calon Presiden yang diharapkan oleh masyarakat secara umum. Hak mengajukan calon (the right to propose candidate) merupakan hak bagi partai politik yang berada di parlemen/legislatif untuk mengajukan calon 
Presiden dan wakil Presiden yang dijamin oleh konstitusi.

\section{Presidential threshold dalam Prinsip Demokrasi Konstitusional}

Negara Indonesia adalah negara hukum yang dituangkan dalam konstitusi negara. Hans Kelsen ${ }^{21}$ mengatakan konstitusi merupakan hukum tertinggi dalam sistem hukum yang menjadi sumber validitas dari norma hukum yang berada dibawahnya. Sebagai hukum tertinggi konstitusi menjadi sumber serta landasan dalam pembentukan peraturan-peraturan perundang-undangan dalam penyelenggaraan negara. Oleh karena itu, setiap peraturan hukum yang dibentuk oleh lembaga pembuat undang-undang dan/atau pejabat penyelenggara negara tidak dibenarkan bertentangan dengan konstitusi.

Mekanisme pengisian jabatan Presiden dan wakil Presiden secara konstitusional diatur melalui ketentuan Pasal 6A UndangUndang Dasar 1945 Ayat (1) Presiden dan wakil Presiden dipilih dalam satu pasangan secara langsung oleh rakyat; (2) pasangan calon Presiden dan wakil Presiden diusulkan oleh partai politik atau gabungan partai politik peserta pemilihan umum sebelum pelaksanaan pemilihan umum; (3) pasangan calon Presiden dan wakil Presiden yang mendapatkan suara lebih dari lima puluh persen dari jumlah suara pemilihan umum dengan sedikitnya dua puluh persen suara disetiap provinsi yang tersebar dilebih dari setengah jumlah provinsi di Indonesia, dilantik menjadi Presiden dan wakil Presiden; (4) dalam hal tidak ada pasangan calon Presiden dan wakil Presiden terpilih, dua pasangan calon yang memperoleh suara terbanyak pertama dan kedua dalam pemilihan umum dipilih oleh rakyat secara langsung dan pasangan yang memperoleh suara terbanyak dilantik sebagai Presiden dan wakil Presiden; (5) tata laksana pemilihan Presiden dan wakil Presiden lebih lanjut diatur dalam undang-undang.

21 Janedjri M. Gaffar. Hukum Pemilu Dan... Op.cit. hlm. 2.
Berdasarkan ketentuan dalam Pasal 6A undang-undang dasar negara Republik Indonesia, sistem pengisian jabatan Presiden dan wakil Presiden telah diatur dan dijamin secara konstitusional. Sistem pemilihan umum Presiden dan wakil Presiden berdasarkan Pasal 6A Ayat (1) menunjukan sistem pemilihan umum yang dilaksanakan dengan demokrasi secara langsung (direct democracy) dimana setiap warga negara dapat menjalankan hak konstitusional masingmasing untuk memilih (the right to vote) Presiden dan wakil Presiden.

Dalam Pasal 6A Ayat (2) yang menentukan bahwa calon Presiden dan wakil Presiden harus diusulkan oleh partai politik sangat berpotensi melanggar hak konstitusional setiap warga negara untuk maju sebagai calon Presiden dan/atau wakil Presiden. Namun demikian, Munir Fuady menyatakan bahwa dalam pelaksanaannya prinsip demokrasi tentu terdapat batasanbatasannya. Akan tetapi batasan tersebut tidak dibenarkan menghilangkan atau mengebiri makna demokrasi yang memberikan hak dan kebebasan bagi warga negara.

Dengan bunyi ketentuan konstitusi Pasal 6A Ayat (2), peluang setiap warga negara untuk maju sebagai calon Presiden dan wakil presiden semakin kecil. Namun tidak tertutup peluang dalam memperjuangkan hak konstitusional warga negara melalui partai politik. Dimana partai politik oleh Firdaus dikatakan sebagai bagian dari kebebasan dan kesetaraan politik untuk berpartisipasi dalam pemerintahan yang dijamin oleh konstitusi. Dengan ketentuan tersebut, maka hak untuk mencalonkan diri (the right to be candidate) menjadi tertutup apabila tidak memiliki kendaran politik (partai politik) dan beralih menjadi hak mengajukan calon (the right to propose candidate) bagi partai politik untuk mengusulkan calon Presiden dan wakil Presiden yang dianggap pantas menurut partai politik.

Teknis pemilihan umum Presiden dan wakil Presiden lebih lanjut diatur melalui perundang-undangan. Pasca amandemen 
undang-undang dasar 1945 pemilihan umum Presiden dan wakil Presiden telah diatur melalui undang-undang No. 23 Tahun 2003 yang dirubah dengan undang-undang No.42 Tahun 2008 dan terakhir dirubah dengan undang-undang No.7 Tahun 2017. Dalam ketentuan undang-undang No.7 Tahun 2017 Pasal 222 "pasangan calon diusulkan oleh partai politik atau gabungan partai politik peserta pemilu yang memenuhi persyaratan perolehan kursi paling sedikit 20\% dari jumlah kursi DPR atau memperoleh $25 \%$ dari suara sah secara nasional pada pemilu anggota DPR sebelumnya".

Ketentuan Pasal 222 Undang-Undang No.7 Tahun 2017 tersebut mengatur ambang batas pencalonan Presiden oleh partai politik peserta pemilihan umum legislatif. Dengan demikian, jumlah kursi partai politik di parlemen yang menentukan partai politik dapat mencalonkan Presiden dan wakil Presiden pada pemilihan umum Presiden dan wakil Presiden. Ambang batas atau presidential threshold yang ditentukan oleh undang-undang sebesar 20\% kursi parlemen, membatasi hak konstitusional partai politik untuk memajukan calon yang dipilih partai politik. Adanya ketentuan Presidential threshold dalam undang-undang pemilihan umum tersebut bertentangan dengan konstitusi, dimana konstitusi merupakan sumber validitas bagi peraturan perundangundangan.

Presidential threshold dalam pengisian jabatan Presiden merupakan pelarangan penggunaan hak konstitusional partai politik dalam berdemokrasi. Firdaus ${ }^{22}$ mengemukakan bahwa partai politik sebagai substansi kebebasan dan kesetaraan guna berpartisipasi dalam pemerintahan melalui kompetisi dalam perebutan jabatan politik yang diperoleh melalui pemilihan umum. Mekanisme pengisian jabatan Presiden dan wakil Presiden di Indonesia pasca amandemen undang-undang dasar, dari sudut pandang demokrasi konstitusional belum

${ }^{22}$ Firdaus. Op. cit. hlm. 15. memberikan jaminan konstitusional secara menyeluruh bagi setiap orang.

Hak konstitusional merupakan hak setiap warga negara yang dijamin dalam konstitusi yang menjadi sumber validitas bagi seluruh rakyat dalam berkehidupan di negara Indonesia. Jaminan terhadap hak-hak asasi manusia sebagai bentuk prinsip demokrasi yang dianut oleh negara Indonesia. Pada pelaksanaan prinsip demokrasi, terdapat batasan dalam berdemokrasi. Sistem pengisian jabatan Presiden berdasarkan Pasal 6A UUD 1945 adalah salah satu bentuk batasan berdemokrasi. Dalam prinsip demokrasi konstitusional, tidak diperkenankan pembatasan-pembatasan mengkebiri substansi demokrasi.

\section{KESIMPULAN}

Mekanisme pengsisian jabatan Presiden dan wakil Presiden secara konstitusional yang diatur dalam Pasal 6A UUD 1945 dalam prinsip demokrasi konstitusional mengkebiri hak konstitusional setiap warga negara. Hak setiap warga negara telah dijamin dalam konstitusi yang diatur dalam Pasal 28 UUD 1945 yang menjadi hak konstitusional. Diantara hak konstitusional antara lain yaitu meliputi hak memilih (the right to vote), hak untuk mencalonkan diri (the right to be candidate), dan hak mengajukan calon (the right to propose candidate).

Mekanisme pengisian jabatan Presiden lebih lanjut diatur melalui undang-undang N0. 7 Tahun 2017 yang salah satu ketentuannya mengatur mengenai ambang batas pencalonan atau presidential threshold. Dengan adanya ketentuan presidential threshold jelas bahwa pemerintahan semakin membatasi hak konstitusional warga negara yaitu hak untuk mencalonkan diri (the right to be candidate) yang dibatasi oleh ketentuan Pasal 6A Ayat (2) UUD 1945. Selain itu, ketentuan Pasal 222 UU No. 7 Tahun 2017 membatasi hak partai politik untuk mengajukan calon (the right to propose candidate) dalam pengisian jabatan Presiden dan/atau wakil Presiden. Hal 
ini bertentangan dengan prinsip demokrasi konstitusional, dimana secara konstitusional tidak diatur adanya ambang batas bagi pencalonan Presiden dan wakil Presiden. Hak mengajukan calon (the right to propose candidate) merupakan hak bagi partai politik yang berada di parlemen/legislatif untuk mengajukan calon Presiden dan wakil Presiden yang dijamin oleh konstitusi.

Hak konstitusional merupakan hak setiap warga negara yang dijamin dalam konstitusi yang menjadi sumber validitas bagi seluruh rakyat dalam berkehidupan dan berbangsa di negara Indonesia. Dengan berpedoman pada konstitusi yang menganut prinsip demokrasi konstitusional, maka pembatasan-pembatasan dalam berdemokrasi tidak dibenarkan mengkebiri makna demokrasi dan hak-hak konstitusional yang dijamin dalam konstitusi itu sendiri.

\section{DAFTAR PUSTAKA}

Buku :

Alrasid, Harun. 1999. Pengisian Jabatan

Presiden. Jakarta : Pustaka Utama

Grafiti.

Astawa, I Gede Pantja dan Suprin Na'a. 2009. Memahami Ilmu Negara Dan Teori

Negara. Cet. 1. Bandung : Refika

Aditama.

Budiardjo, Miriam. 2008. DasarDasar Ilmu Hukum. Edisi Revisi. Cetakan Kedua. Jakarta : Gramedia Pustaka Utama.

Firdaus. 2015. Constitutional Engineering. Desain Stabilitas Pemerintahan Demokrasi \& Sistem Kepartaian. Bandung : Yrama Widya.

Fuady, Munir. 2010. Konsep Negara Demokrasi. Jakarta : Refika Aditama.

Gaffar, Janedjri M. 2013. Demokrasi Dan Pemilu Di Indonesia. Jakarta : Konstitusi Press.

Dalam Yurisprudensi Mahkamah Konstitusi. Jakarta : Konstitusi Pres.

Manan, Bagir. 2003. Lembaga Kepresidenan. Yogyakarta. FH UII Press.
Soekanto, Soerjono dan Sri Mamuji. 2006. Penelitian Hukum Normatif. Jakarta : Rajawali Press.

Sulardi. 2011. Dinamika Pengisian Jabatan Presiden dan Pemberhentian Presiden dan Wakil Presiden di Indonesia. Jurnal UNISIA Vol.33 No.74.

\section{A. Undang-undang}

Undang-Undang Dasar Negara Republik Indonesia 1945.

Undang-Undang No. 23 Tahun 2003

Tentang Pemilihan Umum Presiden Dan Wakil Presiden.

Undang-Undang No. 42 Tahun 2008 Tentang Pemilihan Umum Presiden Dan Wakil Presiden.

Undang-Undang No. 7 Tahun 2017 Tentang Pemilihan Umum.

Putusan Mahkamah Konstitusi (MK) No. 14/PUU-XI/2013 Tentang Pengujian Undang-Undang No. 42 Tahun 2008 Tentang Pemilihan Umum Presiden Dan Wakil Presiden Terhadap Undang-Undang Dasar Negara Republik Indonesia 1945. 
Jurnal AJUDIKASI Vol 1 No 2 Desember 2017, 27-38 